\title{
GAMBARAN TINGKAT PENGETAHUAN REMAJA TENTANG HIV/AIDS DI SMKN 3 MATARAM
}

\author{
Siti Mardiyah WD*, Catur Esty Pamungkas, Rizkia Amilia
}

*Kebidanan, Universitas Muhammadiyah Mataram, sitiwiredarma@gmail.com

\begin{tabular}{l} 
INFO ARTIKEL \\
Riwayat Artikel: \\
Diterima: $28-01-17$ \\
Disetujui: 03-07-17 \\
\hline
\end{tabular}

Kata Kunci:

Tingkat Pengetahuan

Remaja

HIV/AIDS

\begin{abstract}
ABSTRAK
Abstrak: HIV/AIDS adalah penyakit menular seksual yang mengakibatkan kematian. Pergaulan bebas remaja merupakan salah satu indikator yang dapat menularkan penyakit tersebut. Tujuan penelitian ini adalah untuk mengetahui tingkat pengetahuan remaja tentang HIV/AIDS. Metode penelitian yang digunakan adalah penelitian deskriptif. Populasi penelitian ini adalah siswa-siswi kelas 2 SMKN 3 Mataram yang berjumlah 583 dengan jumlah sampel 85 responden dengan teknik pengambilan sampel adalah Accidental Sampling. Data diambil dengan menggunakan kuesioner yang dilakukan di SMKN 3 Mataram. Hasil penelitian ini diperoleh data bahwa lebih banyak siswa 78 responden $(91,76 \%)$ berjenis kelamin Laki-laki dan 7 responden $(8,24 \%)$ berjenis kelamin perempuan, 34 responden (40\%) pendidikan orang tua adalah perguruan tinggi, 41 responden $(48,24 \%)$ sumber informasi adalah televisi, pengetahuan siswa SMA tentang HIV/AIDS sebanyak5 responden (5,88\%) dengan criteria baik, 36 responden $(42,35 \%)$ cukup dan 44 responden $(51,76 \%)$ kurang. Dapat disimpulkan bahwa tingkat pengetahuan remaja tentang HIV/AIDS di SMKN 3 Mataram tersebut adalah kurang.
\end{abstract}

\begin{abstract}
HIV/AIDS is a sexually transmitted disease that results in death. Teenegers free relationship association is one of the indicators that can transmit the disease. The purpose of this research is to know the level of knowledge of teenegers about HIV/AIDS. The research method used is descriptive research. The population of this research is the grade 2 students of SMKN 3 Mataram 583 students with the total sample of respondents 85 with the techniques of sampling is Accidental Sampling. Data taken with the use of questionnaires in SMK N 3 of Mataram. The results of this research were obtained data that more students 78 respondents (91.76\%) -sex male, and 7 respondents (8.24\%) women-sex, 34 respondents (40\%) parent education is College, 41 respondents (48.24\%) the source of information is the television, knowledge of high school students about HIV/AIDS sebanyak5 respondents (5.88\%) with good criteria, 36 respondents (42.35\%) enough and the 44 respondents (51.76\%) less. It can be concluded that the level of knowledge of adolescents about HIV/AIDS in the SMKN 3 Mataram is less.
\end{abstract}

\section{A. LATAR BELAKANG}

Penyakit AIDS (Aquired Immune Deficiency Syndrom) yang disebabkan oleh HIV (Human Immunodeficiency Virus) sudah menyebar dengan cepat diberbagai bagian dunia dan WHO (World Health Organization) sudah mengatakan sebagai sebuah pandemic yang dapat mengancam kelestarian umat manusia. Lebih mengerikan lagi, adalah informasi yang diperoleh dari pusat AIDS International atau Fakultas Kesehatan Masyarakat Universitas Harvard, Amerika Serikat yakni jumlah orang yang terinfeksi virus AIDS yang telah berkembang secara penuh akan terns meningkat sampai 10 kali lipat (Andryan, 2010).
Di seluruh dunia anak-anak remaja baik laki-laki maupun perempuan mengalami berbagai masalah kesehatan reproduksi seperti kehamilan yang tidak diinginkan, Infeksi Menular Seksual (IMS) termasuk infeksi HIV/AIDS. Beberapa data dari WHO menunjukkan tidak kurang dari 111 juta kasus infeksi menular seksual di derita oleh usia di bawah 25 tahun. Kaum muda dan remaja memang sangat beresiko tinggi terhadap Infeksi Menular Seksual (IMS), termasuk HIV/AIDS, karena terbatasnya pengetahuan mereka tentang HIV/AIDS dan pencegahannya (Gunoto, 2006)

Jumlah kasus AIDS di Indonesia, menurut data dari Departemen Kesehatan menyebutkan sampai dengan bulan September 2005 kasus AIDS telah mencapai 4.186 orang dan yang terinfeksi HIV 4.065 orang. Begitu pula 
menurut catatan Depkes pada akhir juni 2006, terdapat secara kumulatif telah mencapai angka 10.859 kasus dengan rincian 6.332 penderita AIDS dan 4.527 pengidap HIV dengan kelompok terbanyak pada usia 20-29 tahun (Sasongko, 2005).

Sebagaimana data yang diperoleh, menunjukkan dalam kurun waktu 13 tahun tercatat 283 orang positif HIV/AIDS. Dengan jumlah penderita sebanyak 61 kasus meninggal. Sebagian besar penderita penyakit HIV/AIDS diakibatkan oleh heteroseks. Mayoritas penderita adalah laki-laki (Dikes Mataram, 2013).

Studi pendahuluan yang dilakukan di SMKN 3 Mataram pada hari : Rabu, 17 Juli 2013 mengenai tingkat pengetahuan siswa SMA tentang HIV/AIDS dengan 10 responden, yang memiliki pengetahuan cukup baik hanya 20\% (2 orang), dan 80\% (8 orang) adalah yang kurang memiliki tingkat pengetahuan tentang HIV/AIDS.

Berdasarkan Latar belakang tersebut di atas, peneliti tertarik untuk meneliti gambaran pengetahuan siswa SMA tentang HIV/AIDS di SMKN 3 Mataram. Dengan harapan penelitian ini dapat memberikan gambaran tentang pengertian HIV/AIDS, cara penularan serta bagaimana pencegahannya.

\section{B. METODE PENELITIAN}

Penelitian ini dilakukan dilakukan di SMKN 3 Mataram pada bulan Oktober 2013. Populasi penelitian ini adalah siswa-siswi kelas 2 SMKN 3 Mataram yang berjumlah 583 dengan jumlah sampel 85 responden dengan teknik pengambilan sampel adalah Accidental Sampling. Data diambil dengan menggunakan kuesioner di SMKN 3 Mataram.

Jenis penelitian ini adalah deskriptif dengan pendekatan cross sectional, rancangan cross sectional merupakan rancangan penelitian dengan melakukan pengumpulan data sekaligus pada sekali waktu (point time approach) (Notoatmodjo, 2010).

\section{HASIL DAN PEMBAHASAN}

\section{Distribusi Siswa SMA berdasarkan Jenis Kelamin}

\section{TABEL 1}

Distribusi Frekuensi Siswa Berdasarkan Jenis Kelamin di SMKN 3 Mataram

\begin{tabular}{ccc}
\hline Jenis Kelamin & $\mathrm{n}$ & $\%$ \\
\hline Laki-Laki & 78 & 91,76 \\
Perempuan & 7 & 8,24 \\
Total & 85 & 100 \\
\hline
\end{tabular}

Berdasarkan data yang didapatkan, lebih banyak siswa SMA yang berjenis kelamin laki-laki 78 orang (91,76\%), hal ini dikarenakan SMKN 3 Mataram merupakan sekolah teknik yang mayoritas jurusannya diminati oleh lakilaki. Pada dasarnya perempuan memulai masa pubertasnya dua tahun lebih awal dari laki-laki (Monks, 2002).

Untuk mendapatkan informasi tentang masalah seksual, anak perempuan lebih senang membaca daripada anak laki-laki yang hanya senang bermain (Hurlock, 2003).

Berdasarkan perbandingan hasil penelitian dengan teori didapatkan hasil bahwa hasil penelitian tidak sesuai dengan teori, pada teori dijelaskan bawa anak perempuan lebih senang membaca daripada anak laki-laki yang hanya senang bermain, secara otomatis anak perempuan memiliki pengetahuan yang lebih dibandingkan dengan anak lakilaki, oleh sebab itu hasil penelitian tidak sesuai dengan teori.

\section{Berdasarkan Pendidikan Orang Tua TABEL 2}

Distribusi Frekuensi siswa Berdasarkan Pendidikan Orang Tua di SMKN 3 Mataram

\begin{tabular}{ccc}
\hline Pendidikan Orang Tua & $\mathrm{n}$ & $\%$ \\
\hline Tidak Sekolah & 9 & 10,58 \\
Tamat SD & 5 & 5,88 \\
Tamat SMP & 21 & 24,70 \\
Tamat SMA & 16 & 18,82 \\
Tamat Perguruan Tinggi & 34 & 40 \\
Total & 85 & 100 \\
\hline
\end{tabular}

Berdasarkan data di atas, sebagian besar siswa SMA di SMKN 3 Mataram yang pendidikan orangtuanya adalah perguruan tinggi 34 orang (40\%). Orangtua siswa banyak berasal dari Kota Mataram dan mempunyai pekerjaan di Kota Mataram, hal ini dikarenakan Mataram merupakan Kota dari Provinsi NTB yang merupakan pusat untuk mencari dan membangun lapangan pekerjaan, sehingga untuk mencari pekerjaan, pendidikanpun menjadi salah satu patokan atau standar untuk dapat bekerja.

Menurut Mubarak (2007) Tidak dapat dipungkiri bahwa makin tinggi pendidikan seseorang semakin mudah pula mereka menerima informasi, dan pada akhirnya makin banyak pula pengetahuan yang dimilikinya. Sebaliknya, jika seseorang tingkat pendidikannya rendah, akan menghambat perkembangan sikap seseorang terhadap penerimaan, informasi dan nilai-nilai yang baru diperkenalkan.

Sesuai dengan teori yang menyatakan bahwa pendidikan seseorang mempengaruhi cara pandangnya terhadap diri dan lingkungannya, sehingga akan membentuk perbedaan sikap antara orang yang berpendidikan lebih tinggi dan berpendidikan rendah (Latipun, 2005).

Hasil penelitian dengan teori didapatkan hasil bahwa teori tidak sesuai dengan hasil penelitian, karena pendidikan orangtua yang perguruan tinggipun tidak menjamin tingkat pengetahuan anaknya, orangtua yang pendidikannya tinggi belum 
tenth memberikan informasi kesehatan yang tepat tentang HIV/AIDS pada anaknya, bisa raja disebabkan oleh kesibukan bekerja orangtua yang jarang bertemu dengan anaknya. Sehingga didaptkan hasil bahwa hasil penelitian tidak sesuai dengan teori.

\section{Berdasarkan Sumber Informasi}

TABEL 3 .

Distribusi Frekuensi Siswa Berdasarkan Sumber Informasi di SMKN 3 Mataram

\begin{tabular}{ccc}
\multicolumn{3}{c}{ Informasi di SMKN 3 Mataram } \\
\cline { 2 - 3 } Sumber Informasi & \multicolumn{2}{c}{ Jumlah } \\
\hline Buku & 16 & 18,82 \\
Televisi & 41 & 48,24 \\
Internet & 19 & 22,35 \\
Orang Tua/Keluarga & 3 & 3,53 \\
Petugas Kesehatan & 6 & 7,06 \\
Total & 85 & 100 \\
\hline
\end{tabular}

Data diperoleh sebagian besar siswa SMA di SMKN 3 Mataram memperoleh sumber informasi dari televisi 41 orang $(48,24 \%)$.

Untuk mendapatkan informasi tentang masalah seksual, anak perempuan lebih senang membaca daripada anak laki-laki yang hanya senang bermain. Sehingga mereka mencari pengetahuan tentang seks dari berbagai sumber media massa, seperti buku, majalah, dan televisi (Hurlock, 2003).

Media massa tersebut merupakan alat saluran (channel) untuk menyampaikan sejumlah informasi sehingga mempermudah masyarakat menerima pesan. Dengan demikian akan mempengaruhi pengetahuan masyarakat tentang inovasi barn (Notoatmodjo, 2005).

Berdasarkan perbandingan hasil penelitian dengan teori didapatkan hasil penelitian tidak sesuai dengan teori, dimana siswa memperoleh sumber informasi tertinggi dari televisi (saluran/chanel) mempunyai pengetahuan yang kurang, sedangkan pada teori dijelaskan bahwa media massa mempengaruhi tingkat pengetahuan seseorang. Dengan demikian hasil penelitian yang telah dilakukan tidak sesuai dengan teori.

\section{Tingkat Pengetahuan Siswa Tentang HIV/AIDS}

\section{TABEL 4}

Distribusi Frekuensi Siswa Berdasarkan Tingkat Pengetahuan di SMKN 3 Mataram

\begin{tabular}{ccc}
\hline Tingkat & \multicolumn{2}{c}{ Jumlah } \\
\hline Pengetahuan & $\mathrm{n}$ & $\%$ \\
Baik & 5 & 5,88 \\
Cukup & 36 & 42,35 \\
Kurang & 44 & 51,76 \\
Total & 85 & 100 \\
\hline
\end{tabular}

Berdasarkan tabel 4. menunjukkan bahwa sebagian besar siswa Kelas 2 di SMKN 3 Mataram memiliki pengetahuan kurang 44 orang $(51,76 \%)$ dan yang memiliki pengetahuan baik hanya 5 orang (5,88\%).
Menurut Peneliti ini menunjukkan dari 85 responden ditemukan sebagian besar dari responden memiliki pengetahuan kurang 44 orang $(51,76 \%)$. Hal ini terlihat dari cara mereka dalam menjawab kuesioner yang meliputi pengertian, penyebab, patofisiologi HIV/AIDS dan lain-lain yang dirasa masih kurang baik.

\section{SIMPULAN DAN SARAN}

Simpulan penelitian ini adalah tingkat pengetahuan remaja tentang HIV/AIDS di SMKN 3 Mataram didapatkan hasil bahwa sebagian besar siswa yang berjenis kelamin laki-laki memiliki pengetahuan kurang 39 orang $(45,88 \%)$, siswa yang orangtuanya memiliki pendidikan perguruan tinggi mempunyai pengetahuan yang kurang 17 orang (20\%), sebagian besar sumber informasi yang diperoleh adalah dari televisi mempunyai pengetahuan kurang 27 orang $(31,77 \%)$ dibandingkan dengan yang lainnya, serta sebagian besar siswa di SMKN 3 Mataram memiliki pengetahuan yang kurang 44 orang $(51,76 \%)$ tentang HIV/AIDS.

Saran penelitian ini diharapkan kepada lembaga pendidikan dan petugas kesehatan agar terus berupaya melaksanakan penyuluhan tentang bahaya HIV/AIDS sehingga dapat meningkatkan pengetahuan remaja dan mencegah berbagai faktor yang dapat menyebabkan terjadinya risiko HIV/AIDS.

\section{E. DAFTAR RUJUKAN}

[1] Andriyan, DN. (2010). Peran Pemerintah Daerah Dalam Menangani HIV/AIDS. Cilacap.

[2] DIKES Mataram. (2013). Situasi Epidemi HIV/AIDS

[3] Gunoto, S. (2006). Kesehatan Reproduksi Remaja Terabaikan. www.suarakaryaonline.com. 10 Juli 2013

[4] Hurlock, E. (2003). Perkembangan Anak Aids 2. Jakarta, Penerbit Erlangga.

[5] Latipun (2005). Psikologi Konseling. Malang, UMM

[6] Mubarok, I. (2007). Promosi Kesehatan. Graha Ilmu : Yogyakarta

[7] Notoatmodjo, S.(2005). Metodologi Penelitian Kesehatan. Jakarta, PT. Rineka Cipta

[8] Sasongko, A. (2005). Acquired Immuno Deficiency Syndrome. Jakarta

[9] SMKN 3 Mataram. (2013). Profil Sekolah.

[10] Sugiyono. (2006). Statistika Untuk Penelitian. Bandung: Alfabeta 